\title{
Efforts to Improve Mathematics Learning Outcomes Determining FPB and KPK Class IV SDN Baros 04 Using Factorization Table Media
}

\section{Dwi Haryani}

SD Negeri Baros 04

dwiharyani9381@gmail.com

\section{Article History}

received 3/12/2020

\begin{abstract}
This research was carried out with the aim of improving student learning outcomes for class IV mathematics at SDN Baros 04 with a factorization table prop on the material to determine the $K P K$ and FPB. This type of research is classroom action research (CAR). The subjects were class IV students, totaling 20 students. This CAR design includes planning, implementation, observation (evaluation), and reflection. Data collection techniques using observation and tests. Data analysis used quantitative descriptive statistics. The results showed an increase in learning outcomes in each cycle. During the pre-cycle the average value of 59.50 with the percentage of completeness (30\%) increased during the first cycle to 67.75 the percentage of completeness (60\%) and increased again in the second cycle with an average value of 80.50 the percentage of completeness (90\%). Thus, it can be concluded that the use of factorization table props on the material to determine GCF and KPK can improve student learning outcomes.
\end{abstract}

Keywords: learning outcomes, mathematics, teaching aids, elementary school

\begin{abstract}
Abstrak
Penelitian ini dilaksanakan dengan tujuan untuk meningkatkan hasil belajar peserta didik muatan pelajaran matematika kelas IV SDN Baros 04 dengan alat peraga tabel faktorisasi pada materi menentukan KPK dan FPB. Jenis penelitian ini adalah penelitian tindakan kelas (PTK). Subjeknya adalah peserta didik kelas IV yang berjumlah 20 peserta didik. Desain PTK ini meliputi perencanaan, pelaksanaan, pengamatan (evaluasi), serta refleksi. Teknik pengumpulan data menggunakan observasi dan tes. Analisis data yang digunakan statistik deskriptif kuantitatif. Hasil penelitian menunjukkan adanya peningkatan hasil belajar pada setiap siklusnya. Saat pra siklus nilai rata-rata 59,50 dengan presentase ketuntasan (30\%) mengalami peningkatan pada saat siklus 1 menjadi 67,75 presentase ketuntasan $(60 \%)$ dan mengalami peningkatan lagi pada siklus 2 dengan nilai rata-rata 80,50 presentase ketuntasan $(90 \%)$. Dengan demikian dapat disimpulkan bahwa penggunaan alat peraga tabel faktorisasi pada materi menentukan FPB dan KPK dapat meningkatkan hasil belajar peserta didik.
\end{abstract}

Kata Kunci : hasil belajar, matematika, alat peraga, sekolah dasar

Social, Humanities, and Education Studies (SHEs): Conference Series https://jurnal.uns.ac.id/shes 


\section{PENDAHULUAN}

Pendidikan di Sekolah Dasar bukan hanya diorientasikan pada memberi bekal kemampuan membaca, menulis dan berhitung, melainkan menyiapkan intelektual, sosial, dan personal siswa secara optimal untuk belajar secara aktif mengembangkan dirinya sebagai pribadi, sebagai anggota masyarakat, sebagai warga negara, dan sebagai makhluk Tuhan Yang Maha Esa (Agus Taufiq, 2018: 1.9)

Kecerdasan merupakan kemampuan untuk memecahkan masalah atau membuat produk yang dihargai di lingkungan kebudayaan. Kecerdasan merupakan kemampuan utama untuk menalar, merencanakan masalah, berfikir, memahami gagasan, menggunakan bahasa dan belajar.

Namun Selama ini, yang dianggap kecerdasan adalah melulu kecerdasan bahasa dan kecerdasan logika (matematika), sedangkan yang lain dianggap tidak atau sekurang-kurangnya "tidak berhubungan langsung" dengan masalah kecerdasan. Menurut pakar psikologi howard garder dalam modul belajar dan pembelajaran (Hanikah, 2013: 60) bahwa proses pembelajaran atau lebih dikenal dengan sebutan kata "mendidik" erat kaitannya dengan semua elemen syaraf dan potensi yang ada di dalam jiwa anak tersebut. Karena, hakikat dari tujuan pembelajaran adalah menumbuhkan semangat anak didik agar berkembang potensinya secara utuh.

Menurut Gatot Muhsetyo (2015 : 1.26) Pembelajaran Matematika adalah proses pemberian pengalaman belajar kepada peserta didik melalui serangkaian kegiatan yang terencana sehingga peserta didik memperoleh kompetensi tentang bahan matematika yang dipelajari. Sedangkan manurut Ahmad Susanto (2013 :186) Pembelajaran matematika adalah suatu proses belajar mengajar yang dibangun oleh guru unruk mengembangkan kreativitas berpikir siswa yang dapat meningkatkan kemampuan berpikir siswa, serta dapat meningkatkan kemampuan mengkrontruksi pengetahuan baru sebagai upaya meningkatkan penguasaan yang baik terhadap materi matematika.

Salah satu karakteristik matematika adalah sebagai studi dengan objek kajian yang bersifat abstrak. Sifat abstrak ini tentu dirasa sulit untuk dicerna peserta didik, terutama pada tingkat sekolah dasar yang masih berada dalam tahap operasional konkret. Guru perlu berhati-hati dalam menanamkan konsep - konsep matematika pada peserta didik. Peserta didik di SD pola berpikirnya masih terbatas pada benda-benda nyata, sedangkan konsep matematika bersifat abstrak. Oleh karena itu, kegiatan pembelajaran matematika di SD haruslah disesuaikan dengan kehidupan peserta didik. Kegiatan pembelajaran matematika yang tidak terkait dengan konteks kehidupan peserta didik akan dirasa kurang bermakna, kurang menarik, dan sulit di pahami peserta didik.

Pembelajaran matematika yang membutuhkan pemikiran abstrak salah satunya materi menentukan FPB dan KPK, bentuk materi diantaranya menentukan bilangan prima, faktor suatu bilangan, menentukan FPB dan KPK mengaplikasikan dalam kehidupan sehari-hari. Kemampuan menentukan FPB dan KPK dalam kehidupan seharihari seperti menetukan jadwal dua atau lebih waktu untuk bersama-sama bertemu, menentukan jumlah pembagian yang sama dengan variabel berbeda. Prasyarat yang perlu dimiliki oleh peserta didik sebelum memahami tentang menentukan FPB dan KPK yakni paham perkalian dan pembagian, bilangan prima, faktorisasi bilangan. Beberapa prasyarat tersebut digunakan untuk memahami menentukan FPB dan KPK.

Kegagalan guru dalam menyampaikan suatu pokok bahasan pada pembelajaran matematika disebabkan saat proses belajar mengajar guru kurang membangkitkan perhatian dan aktivitas peserta didik dalam mengikuti pelajaran matematika. Pelajaran matematika masih berorientasi pada pengembangan aspek kognitif yang mentransfer pengetahuan dari guru ke peserta didik yang diikuti dengan latihan soal untuk membantuk kemampuan sesaat. Metode yang digunakan cenderung masih menggunakan metode konvensional satu arah dan kurang bervariatif sehingga peserta didik cenderung pasif dalam pembelajaran matematika di kelas. Pembelajaran 
matematika masih jarang dikaitkan dengan konteks kehidupan peserta didik sehari-hari. $\mathrm{Hal}$ tersebut merupakan beberapa penyebab dari rendahnya hasil belajar peserta didik.

Menurut Purwanto (2011:46) Hasil belajar adalah perubahan perilaku yang terjadi setelah mengikuti pembelajaran sesuai dengan tujuan pendidikan dalam domain kognitif, afektif dan psikomotorik. Dalam domain kognitif diklasifikasikan menjadi kemampuan hapalan, pemahaman, penerapan, analisis, sintesis, dan evaluasi. Dalam domain afektif hasil belajar meliputi level penerimaan, partisipasi, penilaian, organisasi, dan karakterisasi. Sedang domain psikomotorik terdiri dari level persepsi, kesiapan, gerakan terbimbing, gerakan terbiasa, gerakan kompleks dan kreativititas.

Menurut pendapat Munandi (dalam Rusman, 2012: 124) faktor yang mempengaruhi hasil belajar meliputi faktor internal dan faktor eksternal, yaitu: 1) Faktor Internal, yaitu a) Faktor fisiologis, kondisi kesehatan yang prima, tidak dalam keadaan lelah dan capek, tidak dalam keadaan cacat jasmani, dan sebagainya b) Faktor psikologis, meliputi intelegensi (IQ), perhatian, minat, bakat, motif, motivasi, kognitif, dan daya nalar siswa. 2) Faktor Eksternal yaitu: a) Faktor lingkungan, meliputi lingkungan fisik dan lingkungan sosial misalnya suhu, kelembaban, dan lainlain, b) Faktor instrumental, yaitu berupa kurikulum, sarana, dan guru.

Suatu pembelajaran akan lebih efektif apabila didukung dengan alat peraga atau media pembelajaran, dikarenakan alat peraga merupakan alat bantu yang digunakan guru ketika mengajar untuk membantu memperjelas materi pelajaran yang disampaikan kepada peserta didik dan mencegah terjadinya verbalisme pada diri sasaran pendidikan. Dengan pembelajaran yang kreatif dan menarik serta mampu membetuk konsep secara tepat, seorang guru juga akan dapat menarik dan membuat peserta didik lebih berminat untuk mengikuti pembelajaran yang selama ini dianggap membosankan dan sulit oleh peserta didik. Karena di dalam pembelajaran yang menyenangkan dan tepat akan membuat tujuan pembelajaran yang telah ditetapkan menjadi mudah tercapai.

Menurut Gerlach dan Ely yang dikutip oleh Azhar Arsyad (2011), media pembelajaran apabila dipahami secara garis besar adalah manusia, materi dan kejadian yang membangun kondisi yang membuat siswa mampu memperoleh pengetahuan, ketrampilan atau sikap. Dalam pengertian ini, guru, buku teks, dan lingkungan sekolah merupakan media. Sedangkan menurut Criticos yang dikutip oleh Daryanto (2011:4) media merupakan salah satu komponen komunikasi, yaitu sebagai pembawa pesan dari komunikator menuju komunikan.

Menurut Arif S. Sadiman, dkk (2011) menyebutkan bahwa kegunaan-kegunaan media pembelajaran yaitu: a) Memperjelas penyajian pesan agar tidak terlalu bersifat verbalistis. b) Mengatasi keterbatasan ruang, waktu dan daya indera. c) Penggunaan media pembelajaran yang tepat dan bervariasi dapat mengatasi sikap pasif anak didik. d) Memberikan perangsang belajar yang sama. e) Menyamakan pengalaman. f) Menimbulkan persepsi yang sama.

Berpijak pada permasalahan yang telah diuraikan, penulis melakukan suatu penelitian tindakan kelas (PTK) dengan judul "Upaya Meningkatkan Hasil Belajar Matematika Materi Menentukan FPB dan KPK Kelas IV SDN Baros 04 Dengan Media Tabel Faktorisasi"

\section{METODE}

Pada penelitian ini menggunakan desain penelitian tindakan kelas. Menurut pendapat Suharsimi (2011:3) penelitian tindakan kelas merupakan suatu pencermatan terhadap kegiatan belajar berupa sebuah tindakan, yang sengaja diumculkan dan terjadi dalam sebuah kelas secara bersama. Penelitian tindakan kelas itu sendiri mengharuskan guru untuk selalu berusaha melakukan tindakan pembaharuan (inovasi) dalam proses belajar mengajar. Subjek dalam penelitian ini adalah peserta didik kelas IV SDN Baros 04. Dengan jumlah peserta didik sebanyak 20 peserta didik yang terdiri dari 10 peserta didik laki-laki dan 10 peserta didik perempuan. Objek penelitian ini adalah 
materi Matematika menentukan FPB dan KPK. Dalam pelaksanaannya masing-masing siklus melalui empat tahapan, yakni: tahap perencanaan, tahap pelaksanaan, tahap pengumpulan data dan tahap refleksi. Analisis data yang digunakan dalam penelitian ini adalah statistik deskriptif kuantitatif. Penelitian ini dilaksanakan pada peserta didik kelas IV SDN Baros 04 Tahun Pelajaran 2019/2020. Siklus I dilaksanakan pada tanggal 12 Agustus 2019. Siklus II dilaksanakan pada tanggal 19 Agustus 2019. Teknik pengumpulan data yang dilakukan dengan observasi dan tes.

\section{HASIL DAN PEMBAHASAN}

Penelitian tindakan kelas yang dilakukan melalui dua siklus ini dilakukan untuk mengetahui bagaimana peningkatan hasil belajar peserta didik pada muatan pelajaran matematika materi menentukan FPB dan KPK kelas IV SDN Baros 04. Pada tiap siklusnya terdiri dari satu tindakan yang diwujudkan dalam satu kali pertemuan pembelajaran yang lamanya 2 x 35 menit. Kegiatan perbaikan pembelajaran dalam setiap siklusnya terdiri dari perencanaan yang meliputi menyusun rencana pelaksanaan pembelajaran (RPP), menyiapkan alat peraga (berupa gambar), membuat lembar evaluasi tes tertulis, menyiapkan lembar pengamatan, guru mengadakan evaluasi, guru menganalisis hasil evaluasi, guru mengadakan perbaikan pada peserta didik yang mendapat nilai kurang dari 65 dengan kembali mengerjakan soal latihan. Setelah perencanaan, dilakukanlah pelaksanaan perbaikan pembelajaran yang meliputi kegiatan awal, kegiatan inti, dan kegiatan akhir pembelajaran, serta tindak lanjut. Selanjutnya, pengamatan yaitu analisis terhadap hasil belajar yang sudah didapatkan untuk kemudian dilakukan refleksi yang bertujuan untuk menilai dan mengamati apa yang telah terjadi selama pembelajaran berlangsung untuk kemudian dilakukan perbaikan terhadap kekurangan- kekurangan yang ditemukan dalam proses pembelajaran.

Berdasarkan hasil evaluasi pra siklus, hasil belajar peserta didik masih kurang dalam materi menentukan FPB dan KPK, guru masih menggunakan metode ceramah, tanya jawab serta pendekatan saintifik sehingga pembelajaran kurang menyenangkan. Berdasarkan pembelajaran pra siklus, hasil belajar peserta didik rendah. Nilai yang diperoleh jauh dari yang diharapkan. Masih banyak peserta didik yang memperoleh nilai dibawah Kriteria Ketuntasan Minimal (KKM) yang telah ditetapkan yaitu 65. Nilai ratarata kelasnya hanya 59,5 dari 20 peserta didik yang tuntas sebanyak 6 peserta didik $(30 \%)$ dan sebanyak 14 peserta didik $(70 \%)$ belum tuntas. Peneliti menganggap pelaksanaan pembelajaran Pra siklus belum memuaskan karena hampir semua peserta didik masih kesulitan dalam mengerjakan soal FPB dan KPK. Maka peneliti mengadakan perbaikan pembelajaran.

Setelah dilakukan perbaikan pada siklus I dengan menggunakan alat peraga tabel faktorisasi hasil belajar peserta didik mengalami peningkatan dari pra siklus dengan perolehan nilai rata-rata 67,75 sebanyak 8 peserta didik (40\%) belum tuntas, sedangkan peserta didik yang telah mencapai ketuntasan sebanyak 12 peserta didik (60\%).

Tabel 1. Hasil Belajar Matematika Peserta Didik pada PraSiklus dan Siklus I

\begin{tabular}{clcc}
\hline No & \multicolumn{1}{c}{ Hasil Belajar Peserta Didik } & $\begin{array}{c}\text { Pra } \\
\text { Siklus }\end{array}$ & Siklus I \\
\hline 1 & Jumlah Nilai & 1190 & 1355 \\
2 & Rata-rata Nilai & 59,5 & 67,75 \\
3 & Jumlah Peserta Didik Tuntas & 6 & 12 \\
4 & Jumlah Peserta Didik Belum Tuntas & 14 & 8 \\
5 & Presentase Siswa Tuntas (\%) & 30 & 60 \\
6 & Presentase Siswa Belum Tuntas (\%) & 70 & 40 \\
\hline
\end{tabular}


Berdasarkan tabel di atas dapat dijelaskan bahwa proses pembelajaran belum berhasil karena banyak peserta didik yang nilainya masih di bawah KKM (65) dengan tingkat ketuntasan hanya $60 \%$ sedangkan proses pembelajaran dianggap berhasil apabila tingkat ketuntasan paling tidak mencapai $75 \%$

Dalam pembelajaran Siklus I, peneliti menggunakan menggunakan alat peraga tabel faktorisasi dianggap efektif sehingga berhasil meningkatkan hasil dan aktifitas belajar peserta didik. Hanya saja peserta didik belum terbiasa dan masih agak kesulitan beradaptasi menggunakan alat peraga tabel faktorisasi. Untuk itu harus diadakan perbaikan pembelajaran siklus II dimana peneliti akan tetap menggunakan alat peraga tabel faktorisasi diimbangi dengan latihan soal dengan teknik drill.

Sedangkan pada siklus II penguatan yang diperoleh adalah antusias peserta didik untuk mengikuti pembelajaran semakin meningkat, karena pembelajaran dengan menggunakan alat peraga tabel faktorisasi, materi lebih mudah dipahami oleh peserta didik. Setelah diadakan penelitian pada siklus II menunjukan hasil bahwa kemampuan peserta didik dalam memahami materi pembelajaran menunjukan peningkatan dari siklus I. Hasil analisis terhadap ketercapaian indikator oleh peserta didik dalam perbaikan pembelajaran siklus II dapat dijelaskan sebagai berikut. Ketercapaian nilai rata-rata adalah 80,5 dengan 2 peserta didik (10\%) yang belum tuntas dan 18 peserta didik $(90 \%)$ yang memperoleh nilai tuntas.

Tabel 2. Hasil Belajar Matematika Peserta Didik pada Pra Siklus, Siklus I dan Siklus II

\begin{tabular}{clccc} 
No & Hasil Belajar Peserta Didik & Pra Siklus & Siklus I & Siklus II \\
\hline 1 & Jumlah Nilai & 1190 & 1355 & 1610 \\
2 & Rata-rata Nilai & 59,5 & 67,75 & 80,5 \\
3 & Jumlah Peserta Didik Tuntas & 6 & 12 & 18 \\
4 & Jumlah Peserta Didik Belum Tuntas & 14 & 8 & 2 \\
5 & Presentase Siswa Tuntas (\%) & 30 & 60 & 90 \\
6 & Presentase Siswa Belum Tuntas (\%) & 70 & 40 & 10 \\
\hline
\end{tabular}

Berdasarkan uraian di atas dapat disimpulkan bahwa proses pembelajaran siklus II telah berhasil karena tingkat ketuntasan kelas sebesar 90\% dimana proses pembelajaran dianggap berhasil apabila tingkat ketuntasan paling tidak mencapai $75 \%$. Selain.

Pembelajaran menggunakan alat peraga tabel faktorisasi dianggap efektif dan berhasil meningkatkan hasil belajar peserta didik. Dalam perbaikan pembelajaran siklus II peserta didik lebih antusias karena mereka sebelumnya menggunakan alat peraga tabel faktorisasi pada siklus I dan di siklus II juga disertai dengan latihan soal secara drill. Perbaikan pembelajaran siklus II dianggap berhasil walaupun masih ada 2 peserta didik yang nilainya masih di bawah $\mathrm{KKM}$, sehingga diadakan remidial dan tidak perlu adanya perbaikan pembelajaran selanjutnya.

Adapun peningkatan hasil belajar peserta didik berdasarkan hasil pre test pra siklus, tes siklus I dan tes siklus II dapat dilihat pada grafik rekapitulasi peningkatan hasil belajar matematika menentukan FPB dan KPK sebagai berikut 


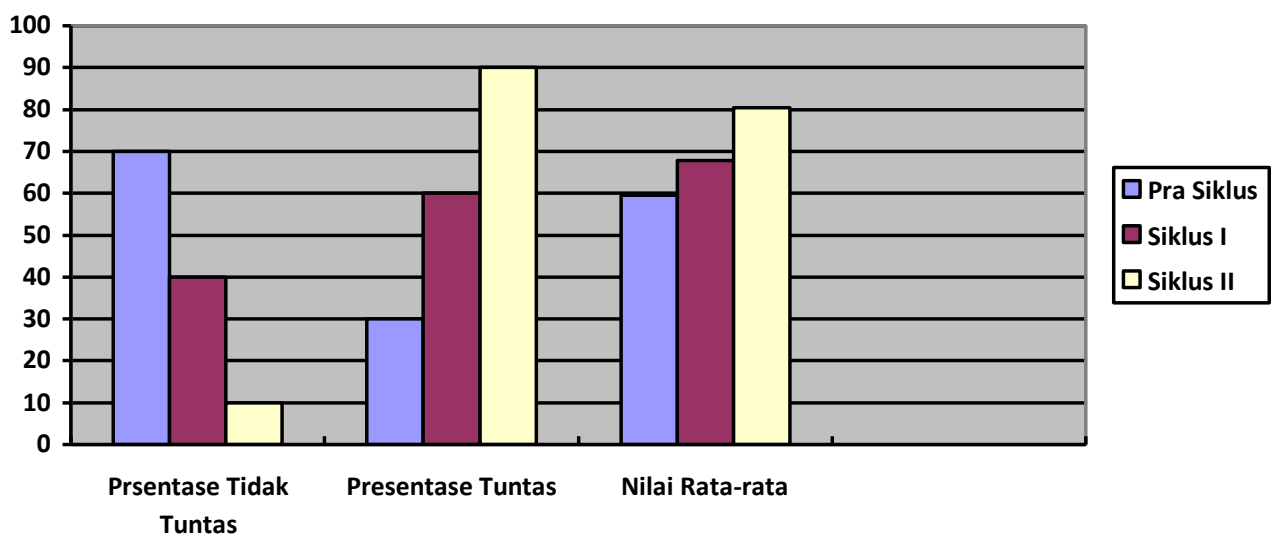

\section{Gambar 1. Grafik Rekapitulasi Peningkatan Hasil Belajar Matematika Materi menentukan FPB dan KPK}

Hasil dari penelitian dan observasi dari setiap siklus menunjukkan bahwa penggunaan alat peraga tabel faktorisasi pada mutan pelajaran Matematika materi menentukan FPB dan KPK terbukti dapat meningkatkan hasil belajar peserta didik kelas IV SDN Baros 04 Kecamatan Ketanggungan Kabupaten Brebes.

\section{SIMPULAN}

Berdasarkan pembahasan dan hasil penelitian maka dapat disimpulkan penggunaan alat peraga tabel faktorisasi pada muatan pelajaran Matematika materi menentuan FPB dan KPK siklus II, ternyata sudah menunjukkan hasil yang maksimal. Hasil belajar yang diperoleh lebih baik dibandingkan pada saat pelaksanaan kegiatan pembelajaran siklus I. Hasil yang diperoleh semua peserta didik menunjukkan kemampuan akhir yang lebih baik dibandingkan dengan kemampuan awal sebelum tindakan. Dari hasil pelaksanaan perbaikan pembelajaran dan refleksi siklus II maka dapat disimpulkan bahwa pelaksanaan tindakan pembelajaran dengan menggunakan alat peraga tabel faktorisasi untuk meningkatkan hasil belajar peserta didik pada materi menentukan FPB dan KPK dapat diakhiri pada siklus II dengan hasil yang memuaskan.

Berdasarkan kesimpulan yang telah diambil melalui analisis data yang terkumpul, dirasa perlu menyampaikan saran-saran sebagai berikut: Bagi peserta didik, diharapkan dapat mengoptimalkan penggunaan alat peraga sehingga dapat meningkatkan pemahaman terhadap materi dan memotivasi peserta didik untuk memperoleh hasil belajar yang lebih baik. Bagi guru, dengan penggunaan alat peraga memberikan dampak positif pada hasil belajar peserta didik, guru diharapkan dapat meningkatkan profesionalisme yaitu dengan mengoptimalkan penggunaan alat peraga atau media pembelajaran untuk meningkatkan kualitas pembelajaran. 


\section{DAFTAR PUSTAKA}

Ahmad, Susanto. (2013). Teori Belajar dan Pembelajaran di Sekolah Dasar. Jakarta: Kencana Prenada Media Group

Arif S. Sadiman, dkk. (2011). Media Pendidikan, Pengertian, Pengembangan, dan Pemanfaatannya. Jakarta: PT. Raja Grafindo Persada.

Arikunto, Suharsimi, dkk. (2011). Penelitian Tindakan Kelas. Jakarta: PT Bumi Aksara. Arsyad, Azhar. (2011). Media Pembelajaran. Jakarta: Raja Grafindo Persada

Daryanto. (2011) Media Pembelajaran. Bandung: Sarana Tutorial Nurani Sejahtera.

Gatot Muhsetyo, dkk. (2011). Pembelajaran Matematika SD. Jakarta: Universitas Terbuka.

Hanikah. 2013. Modul Belajar dan Pembelajaran. Cirebon: Universitas Muhammadiyah Cirebon.

Nana Sudjana. (2013). Dasar-Dasar Proses Belajar Mengajar. Bandung: Sinar Baru Algesindo.

Purwanto, M Ngalim. 1997. Psikologi Pendidikan. Bandung: PT Remaja Rosdakarya Rusman. (2012). Belajar dan Pembelajaran Berbasis Komputer. Bandung: Alfabetha.

Taufiq, Agus. (2011). Materi Pokok Pendidikan Anak di SD. Jakarta: Universitas Terbuka. 